\title{
Heterogeneous photocatalytic degradation of anthraquinone dye Reactive Blue 19: optimization, comparison between processes and identification of intermediate products
}

\author{
Miljana D Radović Vučić', Jelena Z Mitrović', Miloš M Kostić', Nena D Velinov', Slobodan M Najdanović', Danijela V Bojić1 \\ and Aleksandar Lj. Bojić ${ }^{1}$
}

'Department of Chemistry, Faculty of Science and Mathematics, The University of Niš, Višegraska 33, 18000 Niš, Serbia

\begin{abstract}
Treatment of textile wastewater using heterogeneous photocatalysis began in the the last decade and attracted the attention of researchers due to its versatile application. The variety of applications of $\mathrm{TiO}_{2}$ as a photocatalyst was due toits numerous positive properties, such as low operating temperature, biologically inert nature, low energy consumption, water insolubility, availability and photoactivity, low toxicity, high chemical stability, suitable flat band potential, narrow bandgap and the fact that it is environmentally benign. Heterogeneous UV-TiO ${ }_{2}$ photocatalysis is capable of removing organic pollutants from textile wastewater; this has been widely studied, with the technology also having been commercialized in many developing countries. Decolorization of anthraquinone dye Reactive Blue 19 (RB 19) by heterogeneous advanced oxidation processes $\mathrm{TiO}_{2} / \mathrm{UV} / \mathrm{H}_{2} \mathrm{O}_{2}, \mathrm{TiO}_{2} / \mathrm{UV} / \mathrm{KBrO}_{3}$ and $\mathrm{TiO}_{2} / \mathrm{UV} /\left(\mathrm{NH}_{4}\right)_{2} \mathrm{~S}_{2} \mathrm{O}_{8}$ was studied under different conditions and in the presence of electron acceptors such as hydrogen peroxide $\left(\mathrm{H}_{2} \mathrm{O}_{2}\right)$, potassium bromate $\left(\mathrm{KBrO}_{3}\right)$ and ammonium persulphate $\left(\left(\mathrm{NH}_{4}\right)_{2} \mathrm{~S}_{2} \mathrm{O}_{8}\right)$. Decolorization was very fast for all three processes, and complete dye decolorization was achieved in $10 \mathrm{~min}$. The effect of various ions $\left(\mathrm{Cl}^{-}, \mathrm{SO}_{4}{ }^{2-}\right.$ and $\left.\mathrm{HCO}_{3}^{-}\right)$on $\mathrm{RB} 19$ decolorization was also studied. The optimal condition for the decolorization of the dye were determined to be: $\mathrm{TiO}_{2}$ concentration 1 $\mathrm{g} \cdot \mathrm{dm}^{-3}$, electron acceptor concentration $30.0 \mathrm{mmol} \cdot \mathrm{dm}^{-3}$, dye concentration $50.0 \mathrm{mg} \cdot \mathrm{dm}^{-3}$, UV intensity 1950 $\mu \mathrm{W} \cdot \mathrm{cm}^{-2}$, at temperature $25 \pm 0.5^{\circ} \mathrm{C}$. In addition, experiments were performed and compared in three different matrices. In the surface water and dyebath effluent water, the removal efficiency for RB 19 was lower than that achieved in the deionized water because of the interference of complex constituents in the surface water and effluent. LC-MS analysis was carried out and the detected intermediates were compared with the previously published data for anthraquinone dyes.
\end{abstract}

\section{INTRODUCTION}

Textile industries play a vital role in the economic development of many developing countries and therefore also in increasing the gross domestic products of these countries (Masum, 2016). These industries use different raw materials, such as cotton, synthetic and woollen fibres, and chemicals including dyes. Approximately 10000 different synthetic dyes are available in the market and worldwide annual production of these dyes is over $700000 \mathrm{t}$. Nearly $200000 \mathrm{t}$ of synthetic dyes are lost into the environment because of the inefficient dyeing process used in textile industries. According to World Bank estimates, about $17-20 \%$ of industrial wastewater is generated from textile dyeing and finishing treatments (Holkar et al., 2016; Hossain et al., 2018; Ribeiro et al., 2017).

Thus, though the textile industry provides significant economic benefits, it also faces the environmental and social impacts associated with the generation of toxic wastewaters from its processing operations, such as de-sizing, sizing, scouring, bleaching, mercerizing, dyeing, printing, finishing and other processes (Masum, 2016; Miguel et al., 2002; Ledakowicz et al., 2001; Punzi et al., 2015). In order to meet the colour requirement, reactive and azo dyes are highly water-soluble and therefore around $10-20 \%$ of the used dye is washed out with water as effluents which are hazardous (carcinogenic or mutagenic) and toxic to the environment (Ganesh et al., 1994; Weber and Adams, 1995; Zhang et al., 1998).

Various treatment technologies have been developed for the textile wastewater, namely, physical, chemical and biological treatment (Ganesh et al., 1994; Weber and Adams, 1995). In recent years much attention has been given to advanced oxidation processes (AOPs). AOPs include a number of approaches, such as UV photolysis, Fenton process, photo-Fenton process, electro-Fenton process, photoelectro-Fenton, ozonation process, sonolysis, catalytic and radiation-induced biodegradation, etc. (Mohej et al., 2003; Muruganandham and Swaminathan, 2004a; Flox et al., 2006; Chen et al., 2002; Daneshvar and Khataee, 2006; Shu and Chang, 2005; Brillas et al., 2000; Rosenfeldt et al., 2006; Daneshvar et al., 2003; Daneshvar et al., 2005a; Piera et al., 2000; Daneshvar et al., 2007; Elmorsi et al., 2010; Tehrani-Bagha et al., 2010; Wang et al., 2008; Rauf et al., 2010; Ayed et al., 2010; Chen et al., 2008). Photocatalysis relies on the formation and utilization of $\mathrm{OH} \bullet$ radicals and lead to the breakdown of contaminants into water, $\mathrm{CO}_{2}$ and less harmful products. Various semiconductors such as $\mathrm{TiO}_{2}, \mathrm{ZnO}, \mathrm{Fe}_{2} \mathrm{O}_{3}, \mathrm{CdS}, \mathrm{ZnS}$ and $\mathrm{V}_{2} \mathrm{O}_{5}$ can be used for photocatalysis because of their suitable bandgap energy.
CORRESPONDENCE

Miljana D Radović Vučić

EMAIL

mimaradovic@gmail.com

\section{DATES}

Received: 12 December 2018

Accepted: 30 March 2020

\section{KEYWORDS}

anthraquinone dye electron acceptors photocatalysis

Reactive Blue 19

titanium dioxide

\section{COPYRIGHT}

(C) The Author(s)

Published under a Creative Commons Attribution 4.0 International Licence (CC BY 4.0) 
Heterogeneous photocatalysis is based on the reactive properties of photogenerated electron-hole carriers. When a semiconducting material is illuminated by light with an appropriate wavelength, electron-hole pairs are generated. The photogenerated hole, an electron donor, can react with the adsorbed water and hydroxide ions $\left(\mathrm{OH}^{-}\right)$to form hydroxyl radicals $(\mathrm{OH} \bullet)$, whereas the photogenerated electron can react with oxygen to form superoxide radical ion $\left(\mathrm{O}_{2} \bullet^{-}\right)$. Both $\mathrm{OH} \bullet$, $\mathrm{O}_{2}{ }^{-}$and the photogenerated hole are capable of oxidizing a host of organic and inorganic compounds (Linsebigler and Yates, 1995; Fujishima et al., 2000; Fox and Dulay,1993). It has been demonstrated that $\mathrm{TiO}_{2}$ is one of the most significant inorganic photocatalytic materials (Subramanian et al., 2001), in particular the commercial Degussa P25.

Semiconductor $\mathrm{TiO}_{2}$-based photocatalysis has received much attention because of its properties such as non-toxicity, chemical and biological stability, low cost and higher photocatalytic activity. However, for the technical and commercial feasibility of the process, extensive investigations are needed to overcome some problems with $\mathrm{TiO}_{2}$-based photocatalysts (Sharotri and Sud, 2017).

One of the major disadvantages of heterogeneous photocatalysis is the recombination of the photo-generated electron $\left(\mathrm{e}_{\mathrm{cb}}{ }^{-}\right)$and hole $\left(h_{\mathrm{vb}}{ }^{+}\right)$. This step decreases the quantum yield and causes energy wasting. These could be overcome by using electron acceptors or hole scavengers. The addition of the electron acceptor, such as $\mathrm{KBrO}_{3}, \mathrm{H}_{2} \mathrm{O}_{2}$ and $\left(\mathrm{NH}_{4}\right)_{2} \mathrm{~S}_{2} \mathrm{O}_{8}$ enhanced the degradation rate by (i) preventing the electron-hole recombination by accepting the conduction band electron; (ii) increasing the hydroxyl radical concentration; and (iii) generating other oxidizing species $\left(\mathrm{SO}_{4}{ }^{-}\right)$to improve the efficiency of intermediate compounds (Wei et al., 2009).

The objective of the present study was to evaluate the effectiveness of heterogeneous advanced oxidation processes $\mathrm{TiO}_{2} / \mathrm{UV} / \mathrm{KBrO}_{3}, \mathrm{TiO}_{2} / \mathrm{UV} / \mathrm{H}_{2} \mathrm{O}_{2}$ and $\mathrm{TiO}_{2} / \mathrm{UV} /\left(\mathrm{NH}_{4}\right)_{2} \mathrm{~S}_{2} \mathrm{O}_{8}$ at degrading the anthraquinone dye Reactive Blue 19 (RB 19). For all three processes, the influence of background ions $\mathrm{Cl}^{-}, \mathrm{SO}_{4}{ }^{2-}$ and $\mathrm{HCO}_{3}^{-}$, which can compete with the target contaminant for reaction with radicals and holes, was examined. The effect of these ions has not been reported in the literature. Therefore, the influence of the aqueous matrix should also be considered when applying $\mathrm{TiO}_{2} / \mathrm{UV} / \mathrm{KBrO}_{3}, \mathrm{TiO}_{2} / \mathrm{UV} / \mathrm{H}_{2} \mathrm{O}_{2}$ and $\mathrm{TiO} /$ $\mathrm{UV} /\left(\mathrm{NH}_{4}\right)_{2} \mathrm{~S}_{2} \mathrm{O}_{8}$ in practice. For this reason, experiments were performed in three different matrixes (laboratory deionized water, surface water collected from the local Nišava River and dyebath effluent water from a local cotton dyeing facility).

Most investigators have provided information on dyes removal during the degradation process and not much information has been provided about the degradation pathway or intermediate compound formation by heterogeneous advanced oxidation processes $\mathrm{TiO}_{2} / \mathrm{UV} / \mathrm{KBrO}_{3}, \quad \mathrm{TiO}_{2} / \mathrm{UV} / \mathrm{H}_{2} \mathrm{O}_{2}$ and $\mathrm{TiO}_{2} / \mathrm{UV} /$ $\left(\mathrm{NH}_{4}\right)_{2} \mathrm{~S}_{2} \mathrm{O}_{8}$. Hence in the present study, an attempt was made to identify the intermediate compound formed during the dye photocatalytic degradation by using LC-MS analysis.

\section{MATERIALS AND METHODS}

\section{Reagents}

The anthraquinone reactive dye C.I. Reactive Blue 19 (RB 19) $\left(\mathrm{Mw}=626.55 \mathrm{~g} \cdot \mathrm{mol}^{-1}\right)$ was obtained from Sigma-Aldrich (USA) and used without any purification. The hydrogen peroxide $\left(\mathrm{H}_{2} \mathrm{O}_{2}\right)$ solution $(30.0 \%)$, potassium bromate $\left(\mathrm{KBrO}_{3)}\right.$ and ammonium persulfate $\left(\left(\mathrm{NH}_{4}\right)_{2} \mathrm{~S}_{2} \mathrm{O}_{8}\right)$ were of analytical grade and purchased from Merck (Germany). Commercially produced titanium dioxide $\left(\mathrm{TiO}_{2}-\mathrm{P} 25\right)$ was used in all experiments. $\mathrm{TiO}_{2}-\mathrm{P} 25$ was received from Degussa (Frankfurt, Germany). $\mathrm{TiO}_{2}-\mathrm{P} 25$ contains anatase 80.0 and rutile 20.0 with mean particle size of $30.0 \mathrm{~nm}$ and BET surface area of $50.0 \mathrm{~m}^{2} \cdot \mathrm{g}^{-1}$.

\section{Photoreactor}

Photochemical experiments were carried out in a batch photoreactor handmade in our laboratory (Mitrovic et al., 2012). The UV lamps were turned on $10 \mathrm{~min}$ before performing each experiment. The intensity of UV radiation was measured by a UV radiometer Solarmeter model 8.0 UVC (Solartech, USA). The total UV intensity was controlled by turning on different numbers of UV lamps and the maximum intensity was 1950 $\mu \mathrm{W} \cdot \mathrm{cm}^{-2}$ (with all ten UV lamps on) at a distance of $220 \mathrm{~mm}$ from the working solution surface.

\section{Procedures}

A stock solution of RB 19 was prepared by dissolving $1.0 \mathrm{~g}$ dye in $1000.0 \mathrm{~cm}^{-3}$ of deionized water. Working solutions were freshly prepared before irradiation, by diluting the stock to the desired concentration with deionized water. The $\mathrm{pH}$ of the solutions was adjusted by addition of $\mathrm{NaOH}$ or $\mathrm{HCl}\left(0.1 / 0.01 \mathrm{~mol} \cdot \mathrm{dm}^{-3}\right)$ with pH/ISE meter (Orion Star A214, Thermo scientific, USA). The suspensions of dye and $\mathrm{TiO}_{2}$ were magnetically stirred in the dark for $30 \mathrm{~min}$ to attain adsorption-desorption equilibrium between dye and $\mathrm{TiO}_{2}$, and the dye solutions were then treated in the UV reactor.

During irradiation, the solution was magnetically stirred (Are, Velp Scientifica, Italy) at a constant rate, and temperature was maintained at $25 \pm 0.5^{\circ} \mathrm{C}$ by thermostatting. At required time intervals, $4.0 \mathrm{~cm}^{-3}$ of samples were withdrawn, centrifuged (3 $000 \mathrm{r} \cdot \mathrm{min}^{-1}, 15 \mathrm{~min}$ ) and filtered through a $0.20 \mu \mathrm{m}$ regenerated cellulose membrane filter (Agilent Technologies, Germany) to separate the catalyst. Absorbance at $592 \mathrm{~nm}$ was measured using a UV-vis spectrophotometer Shimadzu UV-1800 PC (Shimadzu, Japan) to determine the degree of decolorization of the solution. The removal (\%) of RB 19 dye was calculated as:

$$
\operatorname{Removal}(\%)=\left[1-\frac{c_{t}}{c_{0}}\right] \times 100
$$

where $c_{0}$ and $c_{\mathrm{t}}$ are the concentration values of the dye solution before and after UV irradiation, respectively.

Identifying the degradation product of the RB 19 solution was carried out by LC-MS system. After treatment, the samples of RB 19 were processed using LCQ Fleet mass spectrometer (Thermo Fisher Scientific, USA) with orthogonal electrospray (ESI) source and ion trap (IT) as an analyser. The LCQ Fleet mass spectrometer was linked to the HPLC system (Ultimate 3000, Thermo Fisher Scientific, USA). Thermo Scientific column Dionex Hipersil GOLD C18 was used for separation in a liquid chromatograph. The samples of anthraquinone dye RB 19 were analysed in a negative mode of the mass spectrometer.

To ensure the accuracy, reliability, and reproducibility of the collected data, all experiments were carried out in triplicate, and mean values are recorded. OriginPro 2016 (OriginLab Corporation) software was used for statistical analysis and calculation of the data.

\section{RESULTS AND DISCUSSION}

\section{Influence of experimental parameters on removal efficiency of RB 19}

The preliminary experiments were carried out in order to investigate the effect of UV radiation only, $\mathrm{TiO}_{2}$ without $\mathrm{UV}$ 
radiation, electron acceptors $\left(\mathrm{KBrO}_{3}, \mathrm{H}_{2} \mathrm{O}_{2}\right.$ and $\left(\mathrm{NH}_{4}\right)_{2} \mathrm{~S}_{2} \mathrm{O}_{8}$ without UV radiation and UV irradiation in the presence of $\mathrm{TiO}_{2}$ and electron acceptors. The solution of RB 19 dye (initial dye concentration was $50.0 \mathrm{mg} \cdot \mathrm{dm}^{-3}$ ) was irradiated for 180 min to examine the effect of UV light radiation alone, and there was no observable decrease in residual dye concentration. This indicated that the direct photolysis of RB 19 dye by UV irradiation was slow. Experiments with only electron acceptors were done for $180 \mathrm{~min}$ in the dark. The dye removal efficiency, in that case, was also negligible. No decolorization was observed for the dye solution with $\mathrm{TiO}_{2}$ without UV radiation. But if electron acceptors are applied in combination with UV radiation and $\mathrm{TiO}_{2}$, residual dye concentration rapidly decreases (Fig. 1). Complete decolorization was obtained in less than $15 \mathrm{~min}$, with an initial dye concentration of $50.0 \mathrm{mg} \cdot \mathrm{dm}^{-3}$ in the presence of $1.0 \mathrm{~g} \cdot \mathrm{dm}^{-3} \mathrm{TiO}_{2}$ and $30.0 \mathrm{mmol} \cdot \mathrm{dm}^{-3}$ electron acceptors and under $1950 \mu \mathrm{W} \cdot \mathrm{cm}^{-2}$ light intensity.

Titanium dioxide has drawn much attention from the industry as a good candidate for a large band-gap semiconducting oxide for photodecomposition processes in pollutant treatment, because of its favourable physical/chemical properties, low cost, ease of availability, and high stability (Wang et al., 2013; Yang et al., 2013; Xu et al., 2013; Cetinkaya et al., 2013). Numerous studies in the literature show that $\mathrm{TiO}_{2}$ and other catalysts remain unchanged after the photocatalytic process, confirming their stability even after several cycles of use. (Wan et al., 2012; Li and $\mathrm{Wu}, 2017$; Zhu et al., 2011). Because of all the abovementioned factors, $\mathrm{TiO}_{2}$ was selected as a photocatalyst in the processes examined in this manuscript. The process optimization for the best dye removal efficiency is presented below.

\section{Effect of electron acceptors}

$\mathrm{BrO}_{3}{ }^{-}$ion is an efficient electron acceptor and is used to enhance photocatalytic decolorization rate (Poulios and Tsachpinis, 1999; Gratzel et al., 1990; Sanchez et al., 1998). The effect of the addition of $\mathrm{KBrO}_{3}\left(10.0-100.0 \mathrm{mmol} \cdot \mathrm{dm}^{-3}\right)$ on removal efficiency of RB 19 is shown in Fig. 2. It can be seen that adding a small amount of $\mathrm{KBrO}_{3}$, from 10.0 to $30.0 \mathrm{mmol} \cdot \mathrm{dm}^{-3}$,increases the decolorization from $88.62 \%$ to $96.38 \%$ during the time period of $10 \mathrm{~min}$. The enhancement of the removal efficiencyis due to the reaction between $\mathrm{BrO}_{3}{ }^{-}$ion and conduction band electron (Eq. 2) (Wei et al., 2009; Muneera and Bahnemannb, 2002; San et al. 2001)

$$
\mathrm{BrO}_{3}^{-}+\mathrm{e}_{\mathrm{cb}}^{-}+6 \mathrm{H}^{+} \longrightarrow \mathrm{Br}^{-}+3 \mathrm{H}_{2} \mathrm{O}
$$

With the further increase in $\mathrm{KBrO}_{3}$ concentration from 30.0 to $100.0 \mathrm{mmol} \cdot \mathrm{dm}^{-3}$ the removal efficiency is almost constant. This is due to the adsorption effect of $\mathrm{Br}^{-}$ions on the $\mathrm{TiO}_{2}$ surface, which affects the catalytic activity of $\mathrm{TiO}_{2}$ (San et al., 2001). So the optimum concentration of bromate ion is $30.0 \mathrm{mmol} \cdot \mathrm{dm}^{-3}$ for photocatalytic decolorization of RB 19.

The photocatalytic decolorization of dye occurs on the surface of $\mathrm{TiO}_{2}$, and $\mathrm{O}_{2}$ and $\mathrm{H}_{2} \mathrm{O}_{2}$ are necessary for photocatalytic decolorization (Vesely et al., 1991; Chen and Liu, 2007; Dionysiou et al., 2000; Houas et al., 2001):

$$
\begin{aligned}
& \mathrm{TiO}_{2}\left(\mathrm{e}_{\mathrm{cb}}^{-}\right)+\mathrm{O}_{2} \longrightarrow \mathrm{O}_{2}^{\bullet-} \\
& \mathrm{e}_{\mathrm{cb}}^{-}+\mathrm{H}_{2} \mathrm{O}_{2} \longrightarrow \stackrel{\bullet}{\longrightarrow}+\mathrm{HO}^{-}
\end{aligned}
$$

$\mathrm{H}_{2} \mathrm{O}_{2}$ may be photolyzed or react with superoxide anion to form hydroxyl radical directly:

$$
\begin{aligned}
& \mathrm{H}_{2} \mathrm{O}_{2}+\mathrm{hv} \stackrel{\mathrm{k}_{1}}{\longrightarrow} 2^{\bullet} \mathrm{OH} \\
& \mathrm{H}_{2} \mathrm{O}_{2}+\mathrm{O}_{2}^{--} \longrightarrow
\end{aligned}
$$

The initial concentration of $\mathrm{H}_{2} \mathrm{O}_{2}$ plays an important role in the $\mathrm{TiO}_{2} / \mathrm{UV} / \mathrm{H}_{2} \mathrm{O}_{2}$ process. The effect of the addition of $\mathrm{H}_{2} \mathrm{O}_{2}$ $\left(10.0-100.0 \mathrm{mmol} \cdot \mathrm{dm}^{-3}\right)$ on the decolorization of RB 19 is shown in Fig. 2. The addition of $\mathrm{H}_{2} \mathrm{O}_{2}$ from 10.0 to $30.0 \mathrm{mmol} \cdot \mathrm{dm}^{-3}$ increases the decolorization from $59.52 \%$ to $87.79 \%$ at $10 \mathrm{~min}$. A further increase from 30.0 to $100.0 \mathrm{mmol} \cdot \mathrm{dm}^{-3}$ decreases the removal efficiency to $64.12 \%$ within $10 \mathrm{~min}$. A similar observation has been reported for other organic pollutants (Wei et al., 2009; So et al., 2002; Chu and Wong, 2004). The increase in the decolorization is due to the increase in hydroxyl radical concentration by the addition of $\mathrm{H}_{2} \mathrm{O}_{2}$. At a high dosage of $\mathrm{H}_{2} \mathrm{O}_{2}$ the decrease in decolorization is due to the hydroxyl radical scavenging effect of $\mathrm{H}_{2} \mathrm{O}_{2}$ and recombination of hydroxyl radicals (Daneshvar et al., 2005b; Aleboyeh et al., 2005):

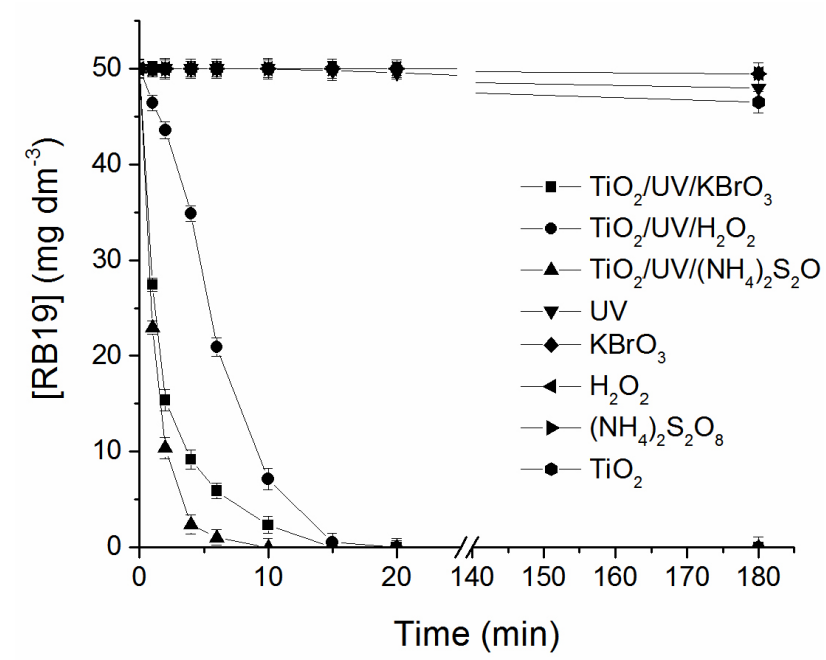

Figure 1. Effect of UV light, $\mathrm{TiO}_{2}$, electron acceptors $\mathrm{TiO}_{2} /$ $\mathrm{UV} / \mathrm{KBrO}_{3}, \mathrm{TiO}_{2} / \mathrm{UV} / \mathrm{H}_{2} \mathrm{O}_{2}$ and $\mathrm{TiO}_{2} / \mathrm{UV} /\left(\mathrm{NH}_{4}\right)_{2} \mathrm{~S}_{2} \mathrm{O}_{8}$ processes on decolorization of RB 19. $[\mathrm{RB} 19]_{0}=50.0 \mathrm{mg} \cdot \mathrm{dm}^{-3}, \mathrm{TiO}_{2}=1.0 \mathrm{~g} \cdot \mathrm{dm}^{-3}$, $\left[\mathrm{KBrO}_{3}\right]_{0}=30.0 \mathrm{mmol} \cdot \mathrm{dm}^{-3},\left[\mathrm{H}_{2} \mathrm{O}_{2}\right]_{0}=30.0 \mathrm{mmol} \cdot \mathrm{dm}^{-3},\left[\left(\mathrm{NH}_{4}\right)_{2} \mathrm{~S}_{2} \mathrm{O}_{8}\right]_{0}$ $=30.0 \mathrm{mmol} \cdot \mathrm{dm}^{-3}$, initial $\mathrm{pH}$ was 7.0, UV radiation intensity was 1 $950 \mu \mathrm{W} \cdot \mathrm{cm}^{-2}$, temperature was $25 \pm 0.5^{\circ} \mathrm{C}$.

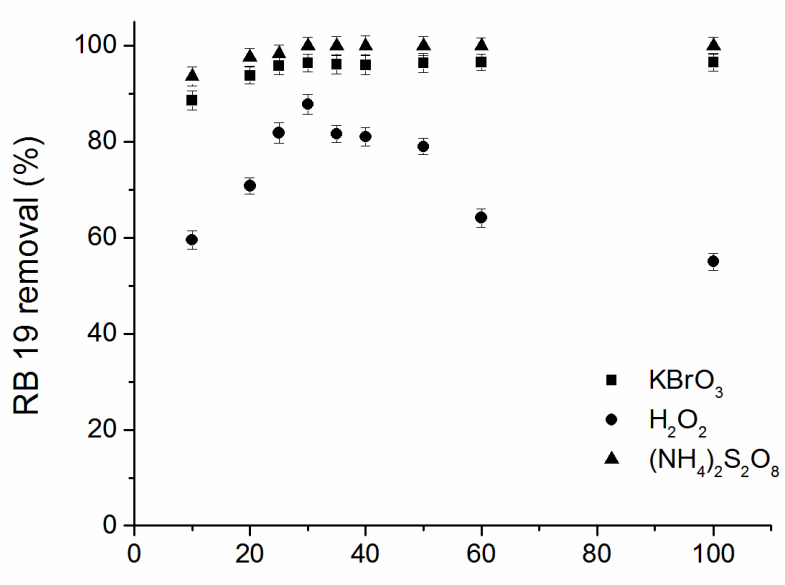

Amount of electron acceptors $\left(\mathrm{mmol} \mathrm{dm}^{-3}\right)$

Figure 2. The removal efficiency of $\mathrm{RB} 19$ by $\mathrm{TiO}_{2} / \mathrm{UV} / \mathrm{KBrO}_{3^{\prime}}, \mathrm{TiO}_{2} /$ $\mathrm{UV} / \mathrm{H}_{2} \mathrm{O}_{2}$ and $\mathrm{TiO}_{2} / \mathrm{UV} /\left(\mathrm{NH}_{4}\right)_{2} \mathrm{~S}_{2} \mathrm{O}_{8}$ processes as a function of initial concentration of electron acceptors. [RB19] $=50.0 \mathrm{mg} \cdot \mathrm{dm}^{-3}, \mathrm{TiO}_{2}=$ $1.0 \mathrm{~g} \cdot \mathrm{dm}^{-3}$, initial $\mathrm{pH} 7.0, \mathrm{UV}$ radiation intensity was $1950 \mu \mathrm{W} \cdot \mathrm{cm}^{-2}$, temperature was $25.0 \pm 0.5^{\circ} \mathrm{C}$. 


$$
\begin{aligned}
& \mathrm{H}_{2} \mathrm{O}_{2}+\mathrm{HO}^{\bullet} \longrightarrow \mathrm{H}_{2} \mathrm{O}+\mathrm{HO}_{2}{ }^{\bullet} \\
& \mathrm{HO}^{\bullet}+\mathrm{HO}_{2} \stackrel{-}{\longrightarrow} \mathrm{H}_{2} \mathrm{O}+\mathrm{O}_{2}
\end{aligned}
$$

$\mathrm{H}_{2} \mathrm{O}_{2}$ is also a powerful hole scavenger. In excess, it may react with holes to produce oxygen and protons. In photocatalytic decolorization, the hole directly oxidizes the dye and with water produces a hydroxyl radical. Hence, the removal efficiency for the dye decreases due to the removal of holes (Pichat et al., 1995).

$$
\mathrm{H}_{2} \mathrm{O}_{2}+\mathrm{h}_{\mathrm{vb}}^{+} \longrightarrow \mathrm{O}_{2}+2 \mathrm{H}^{+}
$$

The effect of the addition of $\mathrm{S}_{2} \mathrm{O}_{8}{ }^{2-}$ on the photolytic oxidation of RB $19\left(50.0 \mathrm{mg} \cdot \mathrm{dm}^{-3}\right)$ was investigated by varying the amount of $\left(\mathrm{NH}_{4}\right)_{2} \mathrm{~S}_{2} \mathrm{O}_{8}$ from 10.0 to $100.0 \mathrm{mmol} \cdot \mathrm{dm}^{-3}$. The results are shown in Fig. 2. The addition of $\left(\mathrm{NH}_{4}\right)_{2} \mathrm{~S}_{2} \mathrm{O}_{8}$ from 10.0 to 30.0 $\mathrm{mmol} \cdot \mathrm{dm}^{-3}$ increases the removal efficiency from $93.63 \%$ to $100.00 \%$ within $10 \mathrm{~min}$. These results are in agreement with earlier research (Poulios and Tsachpinis, 1999, Sanchez et al., 1998). With the further increase of $\left(\mathrm{NH}_{4}\right)_{2} \mathrm{~S}_{2} \mathrm{O}_{8}$ concentration from 30.0 to $100.0 \mathrm{mmol} \cdot \mathrm{dm}^{-3}$ the removal efficiency is almost constant. Addition of persulfate to photocatalytic processes enhances the decolorization rate in the following ways:

$$
\mathrm{TiO}_{2}\left(\mathrm{e}_{\mathrm{cb}}^{-}\right)+\mathrm{S}_{2} \mathrm{O}_{8}^{2-} \longrightarrow \mathrm{SO}_{4}^{\bullet-}+\mathrm{SO}_{4}^{2-}
$$

In the reaction with a photogenerated electron and with a water molecule, the sulfate radical anion $\mathrm{SO}_{4} \bullet^{-}$can generate a hydroxyl radical. The sulfate radical anion is a strong oxidant and participates in the decolorization process. At a high dosage of $\mathrm{S}_{2} \mathrm{O}_{8}^{-2}$, inhibition of reaction occurs due to the increase in the concentration of the $\mathrm{SO}_{4}^{2-}$ ion. On the surface of the $\mathrm{TiO}_{2}$ catalyst there is absorption of the $\mathrm{SO}_{4}^{2-}$ ions. Therefore, catalytic activity is reduced. On the other hand, the adsorbed $\mathrm{SO}_{4}^{-2}$ ion also reacted with photogenerated holes (Eq. 11) and hydroxyl radical (Eq. 12).

$$
\begin{aligned}
& \mathrm{SO}_{4}^{2-}+\mathrm{h}_{\mathrm{vb}}^{+} \longrightarrow \mathrm{SO}_{4}^{-} \\
& \mathrm{SO}_{4}^{2-}+{ }^{\cdot} \mathrm{OH} \longrightarrow \mathrm{SO}_{4}^{\cdot-}+\mathrm{HO}^{-}
\end{aligned}
$$

\section{Effect of initial RB 19 concentration}

Pollutant concentration is a very important parameter in wastewater treatment. The effect of initial dye concentration on decolorization was investigated over a range of 10.0 to 100.0 $\mathrm{mg} \cdot \mathrm{dm}^{-3}$. The removal efficiency of $\mathrm{RB} 19$ by $\mathrm{TiO}_{2} / \mathrm{UV} / \mathrm{KBrO}_{3}$ after 10 min of treatment is shown in Table 1. The results indicate that whileincreasing the initial concentration of dye from 10.0 $\mathrm{mg} \cdot \mathrm{dm}^{-3}$ to $100.0 \mathrm{mg} \cdot \mathrm{dm}^{-3}$ removal efficiency decreased from $100.0 \%$ to $82.55 \%$.

Table 1. Effect of initial dye concentration on removal efficiency of RB 19 by $\mathrm{TiO}_{2} / \mathrm{UV} / \mathrm{KBrO}_{3^{\prime}}, \mathrm{TiO}_{2} / \mathrm{UV} / \mathrm{H}_{2} \mathrm{O}_{2}$ and $\mathrm{TiO}_{2} / \mathrm{UV} /\left(\mathrm{NH}_{4}\right)_{2} \mathrm{~S}_{2} \mathrm{O}_{8}$ processes

\begin{tabular}{lccc}
\hline \multirow{2}{*}{$\begin{array}{l}\text { Conc. of dye } \\
\left(\mathbf{m g} \cdot \mathbf{d m}^{-3}\right)\end{array}$} & \multicolumn{3}{c}{ Removal efficiency (\%) } \\
\cline { 2 - 4 } & $\mathrm{TiO}_{2} / \mathbf{U V} / \mathrm{KBrO}_{3}$ & $\mathrm{TiO}_{2} / \mathbf{U V} / \mathbf{H}_{2} \mathbf{O}_{2}$ & $\mathrm{TiO}_{2} / \mathbf{U V} /\left(\mathbf{N H}_{4}\right)_{2} \mathbf{S}_{2} \mathbf{O}_{8}$ \\
\hline 10 & 100.00 & 95.49 & 100 \\
20 & 98.93 & 93.24 & 100 \\
30 & 98.05 & 89.32 & 100 \\
40 & 97.45 & 85.11 & 100 \\
50 & 96.38 & 87.79 & 100 \\
60 & 92.78 & 65.63 & 98.78 \\
80 & 85.07 & 45.46 & 95.34 \\
100 & 82.55 & 39.14 & 90.05 \\
\hline
\end{tabular}

The results after $10 \mathrm{~min}$ of treatment by $\mathrm{TiO}_{2} / \mathrm{UV} / \mathrm{H}_{2} \mathrm{O}_{2}$ process are shown in Table 1 . With the increase in the initial concentration of dye from $10.0 \mathrm{mg} \cdot \mathrm{dm}^{-3}$ to $100.0 \mathrm{mg} \cdot \mathrm{dm}^{-3}$, removal efficiency decreases from $95.49 \%$ to $39.14 \%$. At high concentrations the penetration of photons entering into the solution decreases, consequently lowering the hydroxyl radical concentration (Ghodbane and Hamdaoui, 2010; Muruganandham and Swaminathan, 2004b; Behnajady et al., 2004; Galindo and Kalt1998). It can be seen that removal efficiency decreased as initial dye concentration increased at the same concentration of $\left(\mathrm{NH}_{4}\right)_{2} \mathrm{~S}_{2} \mathrm{O}_{8}$.

\section{Effect of UV radiation intensity}

By increasing UV radiation intensity, the efficiency of dye decolorization increases considerably. Based on the obtained results, which are shown in Fig. 3, it can be concluded that removal efficiency of dye increases with the increase in radiation intensity from $730 \mu \mathrm{W} \cdot \mathrm{cm}^{-2}$ to $1950 \mu \mathrm{W} \cdot \mathrm{cm}^{-2}$. The lowest difference within the process efficiency is between the radiation intensity $1750 \mu \mathrm{W} \cdot \mathrm{cm}^{-2}$ and $1950 \mu \mathrm{W} \cdot \mathrm{cm}^{-2}$, from which follows that the back lamps in photoreactor have the least contribution to dye decolorization. Results have also shown that the UV intensity tested in the study lies in the linear range and all the photons produced are effectively used (Fig. 3).

The increase in light intensity from $730 \mu \mathrm{W} \cdot \mathrm{cm}^{-2}$ to $1950 \mu \mathrm{W} \cdot \mathrm{cm}^{-2}$ increases the decolorization by $\mathrm{TiO}_{2} / \mathrm{UV} / \mathrm{H}_{2} \mathrm{O}_{2}$ process from 29.70 to $87.79 \%$ within $10 \mathrm{~min}$. The investigation is consistent with previous studies which generally observed an increase in decolorization rate with increasing UV intensity (Mills et al., 1993; Lea and Adesina, 1998). This is a consequence of a higher quantity of generated $\bullet \mathrm{OH}$ radicals, which make oxidative decolorization of anthraquinone dye more efficient.

The influence of UV light intensity on the decolorization of $\mathrm{RB}$ 19 by $\mathrm{TiO}_{2} / \mathrm{UV} / \mathrm{KBrO}_{3}$ and $\mathrm{TiO}_{2} / \mathrm{UV} /\left(\mathrm{NH}_{4}\right)_{2} \mathrm{~S}_{2} \mathrm{O}_{8}$ processes has been monitored by varying the UV radiation intensity as in previous experiments, and similar results were obtained.

\section{Comparison of decolorization by $\mathrm{TiO}_{2} / \mathrm{UV} / \mathrm{KBrO}_{3}, \mathrm{TiO}_{2} / \mathrm{UV} /$ $\mathrm{H}_{2} \mathrm{O}_{2}$ and $\mathrm{TiO}_{2} / \mathrm{UV} /\left(\mathrm{NH}_{4}\right)_{2} \mathbf{S}_{2} \mathbf{O}_{8}$}

In order to optimize the process, a comparison was made between the three heterogeneous oxidation processes after

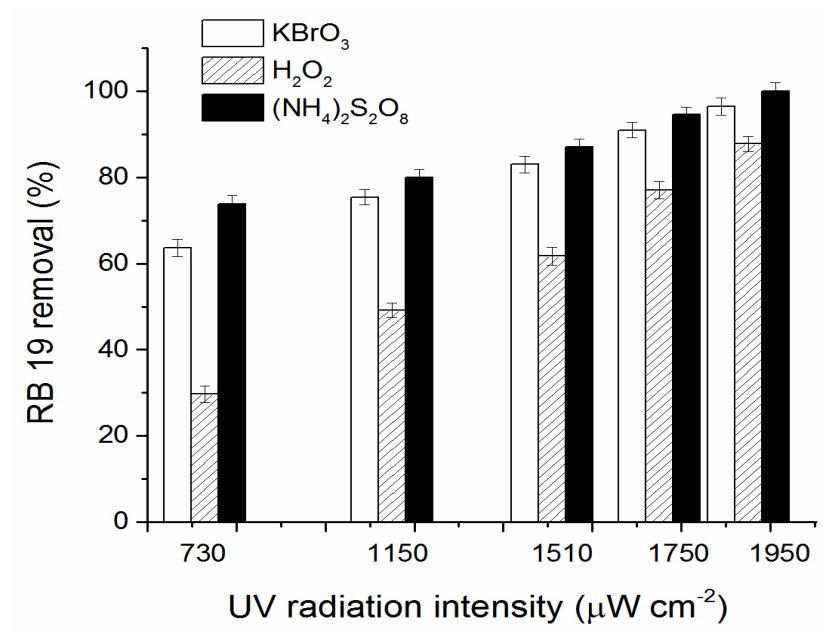

Figure 3. The removal efficiency of $\mathrm{RB} 19$ by $\mathrm{TiO}_{2} / \mathrm{UV} / \mathrm{KBrO}_{3}$, $\mathrm{TiO}_{2} / \mathrm{UV} / \mathrm{H}_{2} \mathrm{O}_{2}$ and $\mathrm{TiO}_{2} / \mathrm{UV} /\left(\mathrm{NH}_{4}\right)_{2} \mathrm{~S}_{2} \mathrm{O}_{8}$ processes as a function of radiation intensity. $[\mathrm{RB} 19]_{0}=50.0 \mathrm{mg} \cdot \mathrm{dm}^{-3}, \mathrm{TiO}_{2}=1.0 \mathrm{~g} \cdot \mathrm{dm}^{-3}$, $\left[\mathrm{KBrO}_{3}\right]_{0}=30.0 \mathrm{mmol} \cdot \mathrm{dm}^{-3},\left[\mathrm{H}_{2} \mathrm{O}_{2}\right]_{0}=30.0 \mathrm{mmol} \cdot \mathrm{dm}^{-3},\left[\left(\mathrm{NH}_{4}\right)_{2} \mathrm{~S}_{2} \mathrm{O}_{8}\right]_{0}=$ $30.0 \mathrm{mmol} \cdot \mathrm{dm}^{-3}$, initial pH 7.0, temperature $=25.0 \pm 0.5^{\circ} \mathrm{C}$. 
10 min of treatment under given conditions. The initial electron acceptor concentrations in these experiments were 30.0 $\mathrm{mmol} \cdot \mathrm{dm}^{-3}$, and the amount of $\mathrm{TiO}_{2}$ was $1.0 \mathrm{~g} \cdot \mathrm{dm}^{-3}$. In the case of photocatalytic decolorization, $\mathrm{S}_{2} \mathrm{O}_{8}^{-2}$ is the most effective for the photodecolorization of RB 19 among the additives studied in this paper. The decolorization efficiencies of RB 19 are in the following order $\mathrm{TiO}_{2} / \mathrm{UV} /\left(\mathrm{NH}_{4}\right)_{2} \mathrm{~S}_{2} \mathrm{O}_{8}(100 \%)>\mathrm{TiO}_{2} / \mathrm{UV} / \mathrm{KBrO}_{3}$ $(96.38 \%)>\mathrm{TiO}_{2} / \mathrm{UV} / \mathrm{H}_{2} \mathrm{O}_{2}(87.79 \%)$.

Electron acceptors such as hydrogen peroxide, potassium bromate and ammonium persulfate were added into the solution in order to enhance the decolorization (Poulios and Tsachpinis, 1999; Gratzel et al., 1990; Sanchez et al., 1998). All the additives showed a beneficial effect on the decolorization of the dye, whereas $\mathrm{S}_{2} \mathrm{O}_{8}^{-2}$ has been found to remarkably enhance the decolorization of pollutant. The efficiency of the $\mathrm{TiO}_{2} / \mathrm{UV} / \mathrm{H}_{2} \mathrm{O}_{2}$ process is comparable to the $\mathrm{TiO}_{2} / \mathrm{UV} / \mathrm{KBrO}_{3}$ process.

$\mathrm{TiO}_{2}$-based photocatalysts also offer advantages such as high physical and chemical stability, low cost, availability, low toxicity, and excellent photoactivity (Banerjee et al., 2014). However, purification of water and wastewater using the $\mathrm{TiO}_{2} /$ $\mathrm{UV} / \mathrm{KBrO}_{3}$ process leads to the formation of bromide ions ( $\mathrm{Lv}$ et al., 2008). Although bromide ion are not harmful to the human body, they can be converted to bromated and other brominated pollutants (Haag and Holgne, 1983; Gunten and Oliveras, 1998) which have suspected carcinogenic potential. Therefore, it is necessary and significant to remove the DBP (disinfection by-product) precursor bromide.

A traditional precursor removal strategy (enhanced coagulation) and novel precursor removal strategy (anion exchange such as activated carbon adsorption processes) are two areas of active research for controlling DBP formation (Johnson and Singer, 2004; Boyer and Singer, 2005). Also, $\mathrm{Br}^{-}$ions are absorbed on the surface of $\mathrm{TiO}_{2}$ and the ability to convert them into $\mathrm{BrO}_{3}^{-}$ions is reduced. In the case of $\mathrm{TiO}_{2} / \mathrm{UV} / \mathrm{H}_{2} \mathrm{O}_{2}$, the final products of dyes degradation are carbon dioxide, water and inert salts (Muruganandham et al., 2004b, Sharma et al., 2016). The persulfates have high solubility and stability at ambient temperature, while the sulfate ions, which are the major products of persulfate reduction, are relatively harmless and considered to be environmentally friendly (Peternel et al., 2012, OlmezHanci et al., 2014). Therefore, these processes are a promising environmental engineering technique.

\section{Effect of salt addition and decolorization test of RB 19 in surface water and dyebath effluent water}

Starting from the assumption that the typical constituents of natural water and wastewater $\left(\mathrm{CO}_{3}^{2-}, \mathrm{HCO}_{3}^{-}, \mathrm{SO}_{4}^{2-}, \mathrm{Cl}^{-}, \mathrm{NO}_{3}^{-}\right.$, $\left.\mathrm{HPO}_{4}^{2-}, \mathrm{H}_{2} \mathrm{PO}_{4}^{-}\right)$can influence the rate of decolorization of the tested substrates, the effects of different concentrations of some ions were studied. Decolorization experiments were performed by dissolving $50.0 \mathrm{mg} \cdot \mathrm{dm}^{-3}$ of dye in deionized water. The added amount of catalyst was $1.0 \mathrm{~g} \cdot \mathrm{dm}^{-3}$ and the initial $\mathrm{pH}$ was 7.0. The obtained results are shown in Table 2.

The decrease in decolorization efficiency of the dye is due to the hole scavenging and hydroxyl radical scavenging properties of chloride and sulfate ions (Wei et al., 2009; Wenhua et al., 2000). The presence of bicarbonate increased the decolorization efficiency. Bicarbonate ions react with hydroxyl radical and produce carbonate radical, $\mathrm{CO}_{3} \bullet^{-}$(Aleboyeh et al., 2012). The carbonate radical is a strong oxidant and very selective for organic compounds.

In order to confirm the behaviour of RB 19 decolorization by $\mathrm{TiO}_{2} / \mathrm{UV} / \mathrm{KBrO}_{3}, \quad \mathrm{TiO}_{2} / \mathrm{UV} / \mathrm{H}_{2} \mathrm{O}_{2}$ and $\mathrm{TiO}_{2} / \mathrm{UV} /\left(\mathrm{NH}_{4}\right)_{2} \mathrm{~S}_{2} \mathrm{O}_{8}$ processes in different practical water samples under optimal conditions, we chose three kinds of water samples as experimental matrices: (i) laboratory deionized water (DW) as the simulation wastewater treatment effluent, (ii) surface water

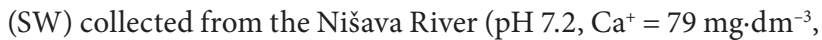
$\mathrm{Mg}^{+}=21 \mathrm{mg} \cdot \mathrm{dm}^{-3}, \mathrm{Na}^{+}=13.42 \mathrm{mg} \cdot \mathrm{dm}^{-3}, \mathrm{Cl}^{-}=69 \mathrm{mg} \cdot \mathrm{dm}^{-3}, \mathrm{SO}_{4}{ }^{2-}$ $=35 \mathrm{mg} \cdot \mathrm{dm}^{-3}, \mathrm{HCO}_{3}^{-}=240 \mathrm{mg} \cdot \mathrm{dm}^{-3}$ ), and (iii) dyebath effluent water (DEW) collected from a local cotton dyeing facilitiy. Dyebath effluent contained $0.050 \mathrm{~g} \cdot \mathrm{dm}^{-3}$ of dye RB 19. Assisting chemicals were also present in reactive dyebath effluent: 40 $\mathrm{g} \cdot \mathrm{dm}^{-3} \mathrm{NaCl}$ (electrolyte, aggregation of dye onto fabric), 13 g. $\mathrm{dm}^{-3} \mathrm{Na}_{2} \mathrm{CO}_{3}$ ( $\mathrm{pH}$ buffer), $0.51 \mathrm{~g} \cdot \mathrm{dm}^{-3} \mathrm{NaOH}$ (produces covalent bonds between dyestuff and fabric), $0.79 \mathrm{~g} \cdot \mathrm{dm}^{-3}$ nacetic acid (neutralization), $0.50 \mathrm{~g} \cdot \mathrm{dm}^{-3}$ alkylphenol polyglycol ether (detergent, washing out of unfixed dyestuff). For preparing a model effluent, dyebath effluent wastewater was diluted to obtain a new solution with $50.0 \mathrm{mg} \cdot \mathrm{dm}^{-3}$ of RB 19. RB 19 was spiked in surface water after the water sample's filtration, with initial concentration of $50 \mathrm{mg} \cdot \mathrm{dm}^{-3}$. Figure 4 shows the removal efficiency of $\mathrm{RB} 19$ obtained by $\mathrm{TiO}_{2} / \mathrm{UV} / \mathrm{KBrO}_{3}, \mathrm{TiO}_{2} / \mathrm{UV} / \mathrm{H}_{2} \mathrm{O}_{2}$ and $\mathrm{TiO}_{2} / \mathrm{UV} /\left(\mathrm{NH}_{4}\right)_{2} \mathrm{~S}_{2} \mathrm{O}_{8}$ processes. Each process was carried out in all three matrices: DW, SW and DEW.

After 10 min irradiation, the $\mathrm{TiO} / \mathrm{UV} / \mathrm{KBrO}_{3}$ process achieved $96.38 \%, 89.63 \%$ and $79.99 \%$ RB 19 removal for the DW, SW, and DEW, respectively; the $\mathrm{TiO}_{2} / \mathrm{UV} / \mathrm{H}_{2} \mathrm{O}_{2}$ process achieved $81.84 \%$, $77.34 \%$ and $69.56 \%$ for the DW, SW, and DEW, respectively; and the $\mathrm{TiO}_{2} / \mathrm{UV} /\left(\mathrm{NH}_{4}\right)_{2} \mathrm{~S}_{2} \mathrm{O}_{8}$ process $100.0 \%, 96.56 \%$ and $86.35 \%$ for the DW, SW, and DEW, respectively. As shown in Fig. 4, in the surface water and dyebath effluent the efficiency of removal of RB 19 was lower than that achieved in the deionized water because of the interference of complex constituents in the surface water and dyebath effluent.

\section{LS-MS analyses}

On the mass spectra obtained after the applied heterogeneous oxidation processes, signals are observed at similar $\mathrm{m} / \mathrm{z}$ values, so it can be assumed that the degradation of the RB 19 dye by the applied processes is probably carried out by a similar mechanism.

After the preliminary fragmentation of RB 19, the samples obtained during treatment with selected heterogeneous advanced oxidation processes were analysed. In Fig. $5 b$ it can be seen from the mass spectrum of the sample after 2 min of treatment that a new ion at $\mathrm{m} / \mathrm{z}$ of 499.1 was reported, compared to the spectrum of untreated dye sample. $\mathrm{MS}^{2}$ ion analysis on $\mathrm{m} / \mathrm{z} 499.1$ gave ions on $\mathrm{m} / \mathrm{z} 435.1$ and $\mathrm{m} / \mathrm{z}$ 408.0. These ions are found at $\mathrm{m} / \mathrm{z}$ values greater than $\Delta \mathrm{m} / \mathrm{z} 16$ of the fragments at $\mathrm{m} / \mathrm{z} 419.1$ and 393.0 of the untreated RB 19 dye sample. Based on these facts, it can be assumed that the formation of monohydroxylated products has occurred.

Table 2. Effect of $\mathrm{Cl}^{-}, \mathrm{SO}_{4}{ }^{2-}$ and $\mathrm{HCO}_{3}{ }^{-}$ions concentrations on the photodecolorization efficiency

\begin{tabular}{lrrrr}
\hline \multirow{2}{*}{ Process } & Conc. ion & \multicolumn{3}{c}{ Decolorization (\%) } \\
\cline { 3 - 5 } & $\left(\mathbf{m m o l} \cdot \mathbf{d m}^{-3}\right)$ & $\mathbf{C l}^{-}$ & $\mathbf{S O}^{42-}$ & $\mathbf{H C O}^{3-}$ \\
\hline $\mathrm{TiO}_{2} / \mathrm{UV} / \mathrm{KBrO}_{3}$ & 0 & $\mathbf{9 8 . 1 2}$ & $\mathbf{9 8 . 1 2}$ & $\mathbf{9 8 . 1 2}$ \\
& 10.0 & 89.39 & 87.92 & 100.0 \\
& 100.0 & 84.01 & 80.15 & 100.0 \\
& 1000.0 & 77.55 & 70.38 & 100.0 \\
\hline $\mathrm{TiO}_{2} / \mathrm{UV} / \mathrm{H}_{2} \mathrm{O}_{2}$ & 0 & $\mathbf{9 6 . 1 3}$ & $\mathbf{9 6 . 1 3}$ & $\mathbf{9 6 . 1 3}$ \\
& 10.0 & 87.40 & 94.42 & 100.0 \\
& 100.0 & 82.17 & 87.51 & 100.0 \\
& 1000.0 & 75.14 & 77.19 & 100.0 \\
\hline $\mathrm{TiO}_{2} / \mathrm{UV} /\left(\mathrm{NH}_{4}\right)_{2} \mathrm{~S}_{2} \mathrm{O}_{8}$ & 0 & $\mathbf{1 0 0 . 0}$ & $\mathbf{1 0 0 . 0}$ & $\mathbf{1 0 0 . 0}$ \\
& 10.0 & 91.40 & 90.85 & 100.0 \\
& 100.0 & 87.15 & 82.64 & 100.0 \\
& 1000.0 & 79.05 & 76.35 & 100.0 \\
\hline
\end{tabular}


In the mass spectrum of the sample after 4 min of treatment, the peak intensity at $\mathrm{m} / \mathrm{z} 602.9$ was significantly reduced, and in the spectrum there was a peak at $\mathrm{m} / \mathrm{z} 317.1$ (Fig.5c). The presence of this ion indicates one of the possible mechanisms of degradation where there is a breakdown of the relationship between the carbon of the aromatic nucleus and nitrogen. $\mathrm{MS}^{2}$ fragmentation of the peak at $\mathrm{m} / \mathrm{z} 317.1$ gave an ion on $\mathrm{m} / \mathrm{z} 253.2$.

After 6 min of treatment, in the mass spectrum of the dye RB 19, no further signal is available on $\mathrm{m} / \mathrm{z} 602.9$ (Fig. 5 (d)). A new signal is an output at $\mathrm{m} / \mathrm{z} 515.1$. MS ${ }^{2}$ analysis of the ion on $\mathrm{m} / \mathrm{z}$ 515.1 gave a peak at $\mathrm{m} / \mathrm{z} 451.1$. The ion on $\mathrm{m} / \mathrm{z} 451.1$ is found at $\mathrm{m} / \mathrm{z}$ values greater than $\Delta \mathrm{m} / \mathrm{z} 16$ from ion to $\mathrm{m} / \mathrm{z} 435.1$ identified by the $\mathrm{MS}^{2}$ analysis of the ion at $\mathrm{m} / \mathrm{z} 499.1$ after 2 min of colour treatment, which is probably due to the attachment of another - $\mathrm{OH}$ radical to an anthraquinone nucleus and the formation of a di-hydroxylated degradation product. $\mathrm{MS}^{3}$ ion analysis on $\mathrm{m} / \mathrm{z} 451.1$ gave ions on $\mathrm{m} / \mathrm{z} 424.9,377.2$ and 360.2 , while $\mathrm{MS}^{2}$ ion analysis on $\mathrm{m} / \mathrm{z} 499.1$ obtained peaks at 435.1 and 408.1.

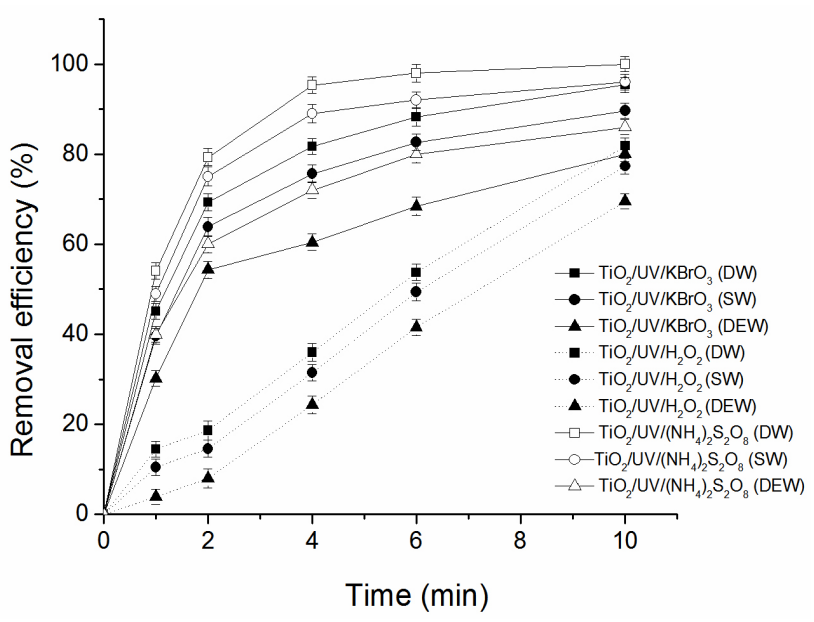

Figure 4. The removal of $\mathrm{RB} 19$ by different oxidation processes: $\mathrm{TiO}_{2} /$ $\mathrm{UV} / \mathrm{KBrO}_{3}\left(\mathrm{pH}=7.0,[\mathrm{RB} 19]_{0}=50.0 \mathrm{mg} \cdot \mathrm{dm}^{-3}, \mathrm{TiO}_{2}=1.0 \mathrm{~g} \cdot \mathrm{dm}^{-3},\left[\mathrm{KBrO}_{3}\right]_{0}\right.$ $=30.0 \mathrm{mmol} \cdot \mathrm{dm}^{-3}, \mathrm{UV}$ intensity $\left.1950 \mu \mathrm{W} \cdot \mathrm{cm}^{-2}\right), \mathrm{TiO}_{2} / \mathrm{UV} / \mathrm{H}_{2} \mathrm{O}_{2}(\mathrm{pH}=7.0$, $[R B 19]_{0}=50.0 \mathrm{mg} \cdot \mathrm{dm}^{-3}, \mathrm{TiO}_{2}=1.0 \mathrm{~g} \cdot \mathrm{dm}^{-3},\left[\mathrm{H}_{2} \mathrm{O}_{2}\right]_{0}=30.0 \mathrm{mmol}^{2} \cdot \mathrm{dm}^{-3}$, UV intensity $\left.1950 \mu \mathrm{W} \cdot \mathrm{cm}^{-2}\right)$ and $\mathrm{TiO}_{2} / \mathrm{UV} /\left(\mathrm{NH}_{4}\right)_{2} \mathrm{~S}_{2} \mathrm{O}_{8}\left(\mathrm{pH}=7.0,[\mathrm{RB} 19]_{0}\right.$ $=50.0 \mathrm{mg} \cdot \mathrm{dm}^{-3}, \mathrm{TiO}_{2}=1.0 \mathrm{~g} \cdot \mathrm{dm}^{-3},\left[\left(\mathrm{NH}_{4}\right)_{2} \mathrm{~S}_{2} \mathrm{O}_{8}\right]_{0}=30.0 \mathrm{mmol} \cdot \mathrm{dm}^{-3}, \mathrm{UV}$ intensity $1950 \mu \mathrm{W} \cdot \mathrm{cm}^{-2}$ )
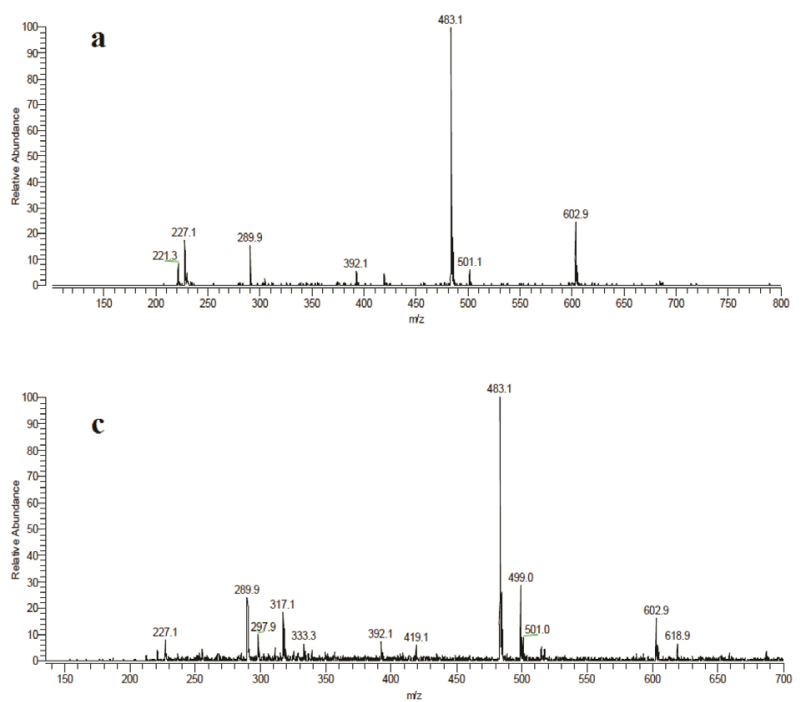

After 10 min of treatment, no new signals were detected, and the intensities of all previously detected peaks were significantly reduced. After a longer treatment time (60 min), the signals of all detected ions have disappeared, indicating further oxidative degradation of intermediate products. Further degradation leads to the formation of low molecular weight aldehydes, organic acids, nitrate and sulfate that cannot be detected by this technique (Amorisco et al., 2011, 2013). These results are consistent with the results for the change in RB 19 dye concentration over time (Fig. 1), which show a significant drop in dye concentration at the same time. Based on the structure of the intermediate degradation products identified by the ESI/IT technique, a possible mechanism of degradation of the anthraquinone dye RB 19 can be predicted (Fig. 6).

\section{CONCLUSIONS}

The decolorization of the RB 19 solutions by $\mathrm{TiO}_{2} / \mathrm{UV} / \mathrm{KBrO}_{3}$, $\mathrm{TiO}_{2} / \mathrm{UV} / \mathrm{H}_{2} \mathrm{O}_{2}$ and $\mathrm{TiO}_{2} / \mathrm{UV} /\left(\mathrm{NH}_{4}\right)_{2} \mathrm{~S}_{2} \mathrm{O}_{8}$ processes strongly depends on the system parameters, such as electron acceptors, dye initial concentration and radiation intensity. From an economic point of view, the $\mathrm{TiO}_{2} / \mathrm{UV} /\left(\mathrm{NH}_{4}\right)_{2} \mathrm{~S}_{2} \mathrm{O}_{8}$ process emerges as the most attractive oxidation system for reactive dye effluents in terms of complete decolorization $(100.00 \%$ in less than $10 \mathrm{~min}$ ), very closely followed by the $\mathrm{TiO}_{2} / \mathrm{UV} / \mathrm{KBrO}_{3}$ process $(96.44 \%$ after $10 \mathrm{~min})$ and $\mathrm{TiO}_{2} / \mathrm{UV} / \mathrm{H}_{2} \mathrm{O}_{2}$ process (87.79\% after $10 \mathrm{~min})$. The presence of chloride and sulfate ions decreased the photocatalytic decolorization, while the presence of bicarbonate increased the decolorization efficiency. All three oxidation processes were carried out in three matrices (laboratory deionized water, surface water collected from the Nišava River and dyebath effluent water from a local cotton dyeing facility). In the surface water and dyebath effluent, the removal efficiency of RB 19 was lower than that achieved in the deionized water because of the interference of complex constituents in the surface water and the dyebath effluent. Lastly, LS-MS analyses were carried out to identify the intermediates produced during dye degradation. At longer treatment times no organic by-products were identified by LS-MS.

\section{ACKNOWLEDGEMENTS}

The authors would like to acknowledge financial support to the Ministry of Education, Science and Technological Development of the Republic of Serbia (Grant No TR34008).
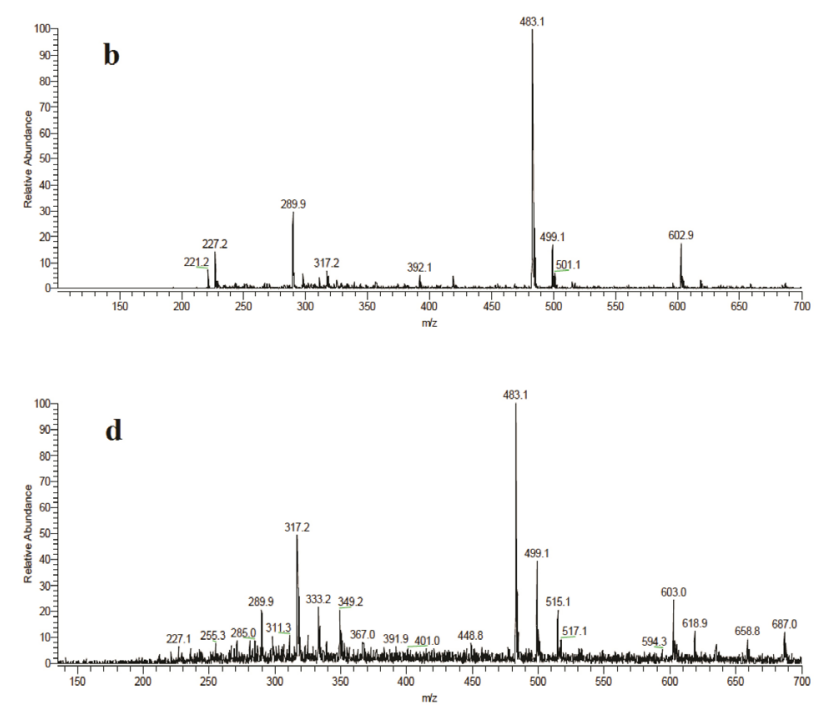

Figure 5. LC-MS spectra of the identified compound in RB 19 solution within 6 min of treatment: (a) RB 19 without treatment, (b) after 2 min (c) after $4 \mathrm{~min}(\mathrm{~d})$ after $6 \mathrm{~min}$ 

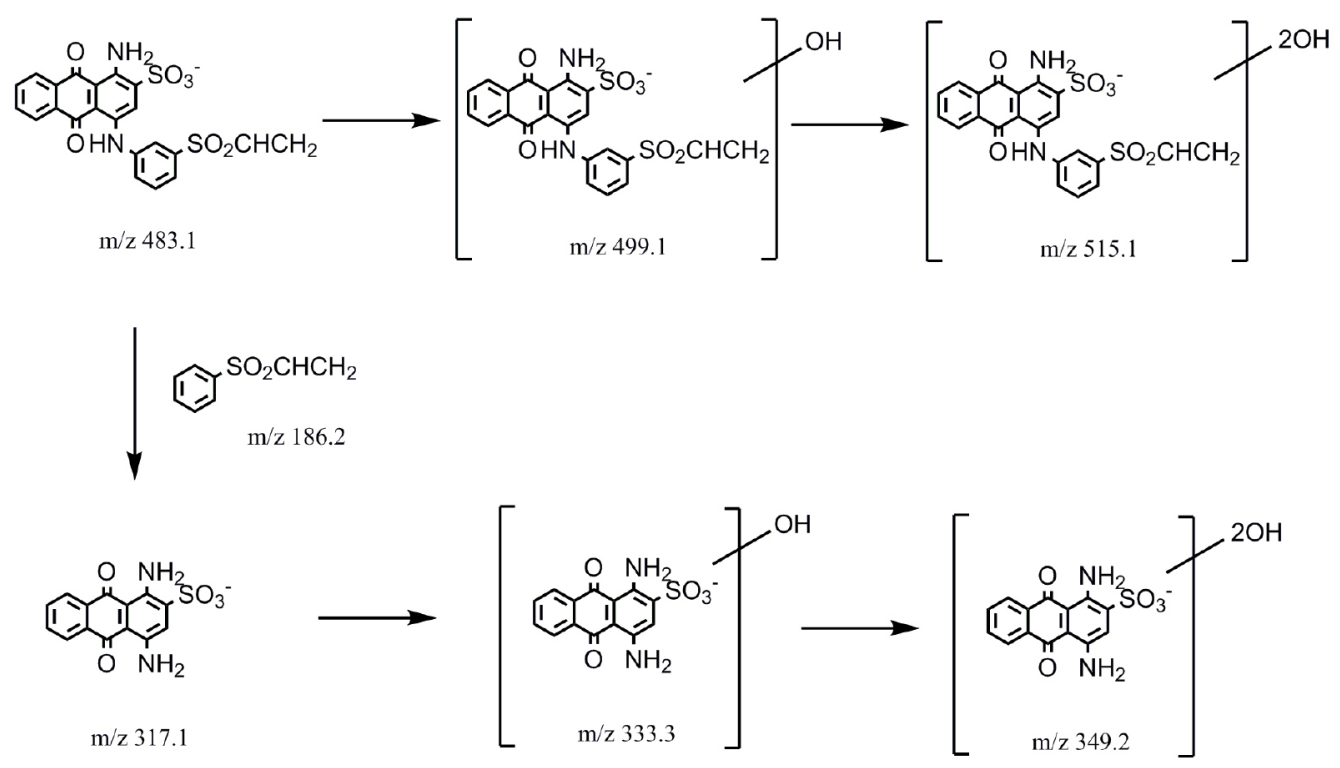

Figure 6. The proposed degradation pathways of RB 19

\section{REFERENCES}

ALEBOYEH A, KASIRI MB and ALEBOYEH H (2012) Influence of dyeing auxiliaries on $\mathrm{AB} 74$ dye degradation by $\mathrm{UV} / \mathrm{H}_{2} \mathrm{O}_{2}$ process. J. Environ. Manage. 113 426-431. https://doi.org/10.1016/j. jenvman.2012.10.008

ALEBOYEH A, MOUSSA Y and ALEBOYEH H (2005) The effect of operational parameters on $\mathrm{UV} / \mathrm{H}_{2} \mathrm{O}_{2}$ decolourisation of Acid Blue 74 Dyes Pigm. 66 129-134. https://doi.org/10.1016/j.dyepig.2004.09.008 AMORISCO A, LOCAPUTO $\mathrm{V}$ and MASCOLO G (2011) Characterization of carbonyl by-products during Uniblu-A ozonation by liquid chromatography/hybrid quadrupole time-offlight/mass spectrometry. Rapid Commun. Mass Spectrom. 25 (13) 1801-1811. https://doi.org/10.1002/rcm.5045

AMORISCO A, LOCAPUTO V, PASTORE C and MASCOLO G (2013) Identification of low molecular weight organic acids by ion chromatography/hybrid quadrupole time-of-flight mass spectrometry during Uniblu-A ozonation. Rapid Commun. Mass Spectrom. 27 (1) 187-199. https://doi.org/10.1002/rcm.6429

AYED L, CHAIEB K, CHEREF A, BAKHROUF A (2010) Biodegradation and decolorization of triphenylmethane dyes by Staphylococcus epidermidis. Desalination 260 (1-3) 137-146. https://doi. org/10.1016/j.desal.2010.04.052

BANERJEE S, PILLAI SC, FALARAS P, O'SHEA KE, BYRNE JA and DIONYSIOU DD (2014) New insights into the mechanism of visible light photocatalysis. J. Phys. Chem. Lett. 5 (15) 2543-2554. http:// dx.doi.org/10.1021/jz501030x

BEHNAJADY MA, MODIRSHAHLA N and SHOKRI M (2004) Photodestruction of Acid Orange 7 (AO7) in aqueous solutions by $\mathrm{UV} / \mathrm{H}_{2} \mathrm{O}_{2}$ : influence of operational parameters. Chemosphere 55 (1) 129-134. https://doi.org/10.1016/j.chemosphere.2003.10.054

BOYER TH and SINGER PC (2005) Bench-scale testing of a magnetic ion exchange resin for removal of disinfection by-product precursors. Water Res. 39 (7) 1265-1276. https://doi.org/10.1016/j. watres.2005.01.002

BRILLAS E, CALPE JC and CASADO J (2000) Mineralization of 2,4-D by advanced electrochemical oxidation processes. Water Res. 34 (8) 2253-2262. https://doi.org/10.1016/S0043-1354(99)00396-6

CETINKAYA T, NEUWIRTHOVA L, KUTLAKOVA KM, TOMASEK $\mathrm{V}$ and AKBULUT H (2013) Synthesis of nanostructured $\mathrm{TiO}_{2} / \mathrm{SiO}_{2}$ as an effective photocatalyst for degradation of acid orange. Appl. Surf. Sci. 279 384-390. https://doi.org/10.1016/j.apsusc.2013.04.121

CHEN F, HE J, ZHAO J and YU JC (2002) Photo-Fenton degradation of Malachite Green catalyzed by aromatic compounds under visible light irradiation. New J. Chem. 26 (3) 336-341. http://dx.doi. org/10.1039/B107404K

CHEN SF and LIU YZ (2007) Study on the photocatalytic degradation of glyphosate by $\mathrm{TiO}_{2}$ photocatalyst. Chemosphere 67 (5) 1010-1017. https://doi.org/10.1016/j.chemosphere.2006.10.054
CHEN YP, LIU SY, YU HQ, YIN H and LI QR (2008) Radiation-induced degradation of methyl orange in aqueous solutions. Chemosphere 72 (4) 532-536. https://doi.org/10.1016/j.chemosphere.2008.03.054

CHU W and WONG CC (2004) The photocatalytic degradation of dicamba in $\mathrm{TiO} 2$ suspensions with the help of hydrogen peroxide by different near UV irradiations. Water Res. 38 (4) 1037-1043. https:// doi.org/10.1016/j.watres.2003.10.037

DANESHVAR N and KHATAEE AR (2006) Removal of azo dye C.I. Acid Red 14 from contaminated water using Fenton, $\mathrm{UV} / \mathrm{H}_{2} \mathrm{O}_{2}$, $\mathrm{UV} / \mathrm{H}_{2} \mathrm{O}_{2} / \mathrm{Fe}(\mathrm{II}), \mathrm{UV} / \mathrm{H}_{2} \mathrm{O}_{2} / \mathrm{Fe}(\mathrm{III})$, and $\mathrm{UV} / \mathrm{H}_{2} \mathrm{O}_{2} / \mathrm{Fe}(\mathrm{III}) /$ oxalate processes: a comparative study. J. Environ. Sci. Health A 41 (3) 315328. https://doi.org/10.1080/10934520500423196

DANESHVAR N, SALARI D and KHATAEE AR (2003) Photocatalytic degradation of azo dye Acid Red 14 in water: investigation of the effect of operational parameters. J. Photochem. Photobiol. A 157 (1) 111-116. https://doi.org/10.1016/S1010-6030(03)00015-7

DANESHVAR N, SALARI D, NIAIE A, RASOULIFARD MH and KHATAEE AR, (2005a) Immobilization of $\mathrm{TiO} 2$ nanopowder on glass beads for the photocatalytic decolorization of an azo dye C.I. Direct Red 23. J. Environ. Sci. Health A 40 (8) 1605-1617. https://doi. org/10.1081/ESE-200060664

DANESHVAR N, RABBANI M, MODIRSHAHLA N and BEHNAJADY MA (2005b) Photooxidative degradation of Acid Red 27 in tubular continuous-flow photoreactor: influence of operational parameters and mineralization products. J. Hazardous Mater. B 118 (1-3) 155160. https://doi.org/10.1016/j.jhazmat.2004.10.007

DANESHVAR N, KHATAEE AR, RASOULIFARD $\mathrm{MH}$ and HOSSEINZADEH E (2007) Removal of C.I. Acid Orange 7 from aqueous solution by UV irradiation in the presence of $\mathrm{ZnO}$ nanopowder. J. Hazardous Mater. 143 (1-2) 95-101. https://doi. org/10.1016/j.jhazmat.2006.08.072

DIONYSIOU DD, SUIDAN MT, BEKOU E, BAUDIN I and LAINE JM (2000) Effect of ionic strength and hydrogen peroxide on the photocatalytic degradation of 4-chlorobenzoic acid in water. Appl. Catal. B: Environ, 26 (3) 153-171. https://doi.org/10.1016/ S0926-3373(00)00124-7

ELMORSI TM, RIYAD YM, MOHAMED ZH, ABD EL BARY HMH (2010) Decolorization of Mordant red 73 azo dye in water using H2O2/UV and photo-Fenton treatment. J. Hazardous Mater. 174 (1-3) 352-358. https://doi.org/10.1016/j.jhazmat.2009.09.057

FLOX C., AMMAR S, ARIAS C, BRILLAS E, VARGAS-ZAVALA AV and ABDEIHEDI R (2006) Electro-Fenton and photoelectronFenton degradation of indigo carmine in acidic aqueous medium. Appl. Catal. B 67 (1-2) 93-104. https://doi.org/10.1016/j. apcatb.2006.04.020

FOX MA and DULAY MT (1993) Heterogeneous photocatalysis. Chem. Rev. 93 (1) 341-357. https://doi.org/10.1021/cr00017a016

FUJISHIMA A, RAO TN and TRYK DA (2000) Titanium dioxide 
photocatalysis. J. Photochem. Photobiol. C 1 (1) 1-21. https://doi. org/10.1016/S1389-5567(00)00002-2

GALINDO C and KALT A (1998) UV- $\mathrm{H}_{2} \mathrm{O}_{2}$ oxidation of monoazo dyes in aqueous media: a kinetic study. Dyes Pigm. 40 (1) 27-35. https:// doi.org/10.1016/S0143-7208(98)00027-8

GANESH R, BOARDMAN GD and MICHELSON D (1994) Fate of azo dyes in sludges. Water Res. 28 (6) 1367-1376. https://doi. org/10.1016/0043-1354(94)90303-4

GHODBANE $\mathrm{H}$ and HAMDAOUI O (2010) Decolorization of antraquinonic dye C.I. Acid Blue 25, in aqueous solution by direct $\mathrm{UV}$ irridation, $\mathrm{UV} / \mathrm{H}_{2} \mathrm{O}_{2}$ and UV/Fe(II) processes. Chem. Eng. J. 160 (1) 226-231. https://doi.org/10.1016/j.cej.2010.03.049

GRATZEL, CK, JIROUSEK M and GRATZEL M (1990) Decomposition of organophosphorus compounds on photoactivated $\mathrm{TiO}_{2}$ surfaces. J. Mol. Catal. 60 (3) 375-387. https://doi. org/10.1016/0304-5102(90)85260-O

GUNTEN U and OLIVERAS Y (1998) Advanced oxidation of bromidecontaining waters: bromated formation mechanisms. Environ. Sci. Technol. 32 (1) 63-70. https://doi.org/10.1021/es970477j

HAAG WR and HOLGNE J (1983) Ozonation of bromide-containing waters: kinetics of formation of hypobromous acid and bromate. Environ. Sci. Technol. 17 (5) 261-267. https://doi.org/10.1021/ es00111a004

HOLKAR CR, JADHAV AJ, PINJARI DV, MAHAMUNI NM and PANDIT AB (2016) A critical review on textile wastewater treatments: possible approaches. J. Environ. Manage. 182 351-366. https://doi.org/10.1016/j.jenvman.2016.07.090

HOSSAIN L, SARKER SK and KHAN MS (2018) Evaluation of present and future wastewater impacts of textile dyeing industries in Bangladesh. Environ. Dev. 26 23-33. https://doi.org/10.1016/j. envdev.2018.03.005

HOUAS A, LACHHEB H, KSIBI M, ELALOUI E, GUILLARD C and HERRMANN JM (2001) Photocatalytic degradation pathway of methylene blue in water. Appl. Catal. B: Environ. 31 (2) 145-157. https://doi.org/10.1016/S0926-3373(00)00276-9

JOHNSON CJ and SINGER PC (2004) Impact of a magnetic ion exchange resin on ozone demand and bromated formation during drinking water treatment. Water Res. 38 (17) 3738-3750. https://doi org/10.1016/j.watres.2004.06.021

LEA J and ADESINA AA (1998) The photo-oxidative degradation of sodium dodecyl sulfate in aerated aqueous $\mathrm{TiO}_{2}$ suspension. $J$. Photochem. Photobiol. A 118 (2) 111-122. https://doi.org/10.1016/ S1010-6030(98)00375-X

LEDAKOWICZ S, SOLECKA M and ZYLLA R (2001) Biodegradation, decolourisation and detoxification of textile wastewater enhanced by advanced oxidation processes. J. Biotechnol. 89 (2-3) 175-184. https://doi.org/10.1016/s0168-1656(01)00296-6

LI W and WU H (2017) Sodium citrate functionalized reusable Fe3O4@ $\mathrm{TiO} 2$ photocatalyst for water purification. Chem. Phys. Lett. 686 178-182. https://doi.org/10.1016/j.cplett.2017.08.046.

LINSEBIGLER AL, LU GQ and YATES JT (1995) Photocatalysis on TiO2 Surfaces: Principles, Mechanisms, and Selected Results. Chem. Rev. 95 (4) 735-758. https://doi.org/10.1021/cr00035a013

LV L, WANG Y, WEI M and CHENG J (2008) Bromide ion removal from contaminated water by calcined and uncalcined $\mathrm{MgAl}-\mathrm{CO} 3$ layered double hydroxides. J. Hazardous Mater. 152 (3) 1130-1137. https://doi.org/10.1016/j.jhazmat.2007.07.117

MASUM M (2016) The Bangladesh textile-clothing industry: a demandsupply review. Social Syst. Stud. 9 109-139.

MIGUEL R, VICTOR S, SANTIAGO E and CESAR P (2002) PhotoFenton treatment of a bio-recalcitrant wastewater generated in textile activities: biodegradability of the phototreated solution. J. Photochem. Photobiol. A: Chem. 151 (1-3) 129-135. https://doi. org/10.1016/S1010-6030(02)00148-X

MILLS A, DAVIS R and WORSLEY D (1993) Water purification by semiconductor photocatalysis. Chem. Soc. Rev. 22 (6) 417-434 http://dx.doi.org/10.1039/CS9932200417

MITROVIC J, RADOVIC M, BOJIC D, ANDJELKOVIC T, PURENOVIC M and BOJIC A (2012) Decolorization of textile azo dye Reactive Orange 16 with UV/ $\mathrm{H}_{2} \mathrm{O}_{2}$ process. J. Serb. Chem. Soc. 77 (4) 465-481. https://doi.org/10.2298/JSC110216187M

MOHEJ EL-DEIN A, LIBRA JA and WIESMANN U (2003). Mechanism and kinetic model for the decolorization of the azo dye Reactive
Black 5 by hydrogen peroxide and UV radiation. Chemosphere $\mathbf{5 2}$ (6) 1069-1077. https://doi.org/10.1016/S0045-6535(03)00226-1

MUNEERA $M$ and BAHNEMANNB D (2002) Semiconductormediated photocatalyzed degradation of two selected pesticide derivatives, terbacil and 2,4,5-tribromoimidazole, in aqueous suspension. Appl. Catal. B: Environ. 36 (2) 95-111. https://doi. org/10.1016/S0926-3373(01)00282-X

MURUGANANDHAM $M$ and SWAMINATHAN M (2004a) Decolourisation of Reactive Orange 4 by Fenton and photo-Fenton oxidation technology. Dyes Pigm. 63 (3) 315-321. https://doi. org/10.1016/j.dyepig.2004.03.004

MURUGANANDHAM $M$ and SWAMINATHAN M (2004b) Photochemical oxidation of reactive azo dye with $\mathrm{UV}-\mathrm{H}_{2} \mathrm{O}_{2}$ process. Dyes Pigm. 62 (3) 269-275. https://doi.org/10.1016/j. dyepig.2003.12.006

OLMEZ-HANCI T, ARSLAN-ALATON I and GENC B (2014) Degradation of the nonionic surfactant Triton ${ }^{\text {Tax }} \mathrm{X}-45$ with HO and $\mathrm{SO}_{4} .^{-}-$based advanced oxidation processes. Chem. Eng. J. 239332 340. https://doi.org/10.1016/j.cej.2013.11.033

PETERNEL I, KUSIC H, MARIN V and KOPRIVANAC N (2012) $\mathrm{UV}$-assisted persulfate oxidation : the influence of cation type in persulfate salt on the degradation kinetic of azo dye pollutant. React. Kinet. Mech. Catal. 108 (1) 17-39. http://dx.doi.org/10.1007/ s11144-012-0502-9

PICHAT P, GUILLARD C, AMALRIC L, RENARD A and PLAIDY $\mathrm{O}$ (1995) Assessment of the importance of the role of $\mathrm{H}_{2} \mathrm{O}_{2}$ and $\mathrm{O}_{2}{ }^{--}$in the photocatalytic degradation of 1,2-dimethoxybenzene. Sol. Energy Mater. Sol. Cells 38 (1-4) 391-399. https://doi. org/10.1016/0927-0248(94)00231-2

PIERA E, CALPE JC, BRILLAS E, DOMENECH X and PERAL J (2000) 2,4-Dichlorophenoxyacetic acid degradation by catalyzed ozonation: $\mathrm{TiO}_{2} / \mathrm{UVA} / \mathrm{O}_{3}$ and $\mathrm{Fe}(\mathrm{II}) / \mathrm{UVA} / \mathrm{O}_{3}$ systems. Appl. Catal. B. 27 (3) 169-177. https://doi.org/10.1016/S0926-3373(00)00149-1

POULIOS I and TSACHPINIS I (1999) Photodegradation of the textile dye Reactive Black 5 in the presence of semiconducting oxides. J. Chem. Technol. Biotechnol. 74 (4) 349-357. http://dx.doi.org/10.1002/ (SICI)1097-4660(199904)74:4\%3C349::AID-JCTB5\%3E3.0.CO;2-7

PUNZI M, NILSSON F, ANBALAGAN A, SVENSSON BM, JONSSON K, MATTIASSON B and JONSTRUP $M$ (2015) Combined anaerobic-ozonation process for treatment of textile wastewater: removal of acute toxicity and mutagenicity. J. Hazardous Mater. 292 52-60. https://doi.org/10.1016/j.jhazmat.2015.03.018

RAUF MA, MEETANI MA, KHALEEL A and AHMED A (2010) Photocatalytic degradation of Methylene Blue using a mixed catalyst and product analysis by LC/MS. Chem. Eng. J. 157 (2-3) 373-378. https://doi.org/10.1016/j.cej.2009.11.017

RIBEIRO MCM, STARLING MCVM, LEAO MMD and DE AMORIM CC (2017) Textile wastewater reuse after additional treatment by Fenton's reagent. Environ. Sci. Pollut. Res. 24 (7) 6165-6175. https:// doi.org/10.1007/s11356-016-6921-9

ROSENFELDT EJ, LINDEN KG, CANONICA S and VON GUNTEN U (2006) Comparison of the efficiency of ${ }^{\circ} \mathrm{OH}$ radical formation during ozonation and the advanced oxidation processes $\mathrm{O}_{3} / \mathrm{H}_{2} \mathrm{O}_{2}$ and $\mathrm{UV} /$ $\mathrm{H}_{2} \mathrm{O}_{2}$. Water Res. 40 (20) 3695-3704. https://doi.org/10.1016/j. watres.2006.09.008

SAN N, HATIPOGLU A, KOCTURK G and CINAR Z (2001) Prediction of primary intermediates and the photodegradation kinetics of 3-aminophenol in aqueous $\mathrm{TiO}_{2}$ suspensions. J. Photochem. Photobiol. A: Chem. 139 (2-3) 225-232. https://doi.org/10.1016/ S1010-6030(01)00368-9

SANCHEZ L, PERAL J and DOMENECH X (1998) Aniline degradation by combined photocatalysis and ozonation. Appl. Cat. B Environ. 19 (1) 59-65. https://doi.org/10.1016/S0926-3373(98)00058-7

SHARMA J, MISHRA IM and KUMAR V (2016) Mechanistic study of photo-oxidation of Bisphenol-A (BPA) with hydrogen peroxide $\left(\mathrm{H}_{2} \mathrm{O}_{2}\right)$ and sodium persulfate (SPS). J. Environ. Manage. 166 (15) 12-22. https://doi.org/10.1016/j.jenvman.2015.09.043

SHAROTRI N and SUD D (2017) Visible light responsive Mn-Sco-doped $\mathrm{TiO}_{2}$ photocatalyst - Synthesis, characterization and mechanistic aspect of photocatalytic degradation. Sep. Purif. Technol. 183 382-391. https://doi.org/10.1016/j.seppur.2017.03.053

SHU HY and CHANG MC (2005) Decolorization effect of six azo dyes by $\mathrm{O}_{3}, \mathrm{UV} / \mathrm{O}_{3}$ and $\mathrm{UV} / \mathrm{H}_{2} \mathrm{O}_{2}$ processes. Dyes Pigm. 65 (1) 25-31. 
https://doi.org/10.1016/j.dyepig.2004.06.014

SO M, CHENG MY, YU JC and WONG PK (2002) Degradation of azo dye procion Red MX-5B by photocatalytic oxidation. Chemosphere 46 (6) 905-912. https://doi.org/10.1016/S0045-6535(01)00153-9

SUBRAMANIAN V, WOLF E and KAMAT PV (2001) Semiconductormetal composite nanostructures. to what extent do metal nanoparticles improve the photocatalytic activity of $\mathrm{TiO}_{2}$ films? J. Phys. Chem. B 105 (46) 11439-11446. https://doi.org/10.1021/ jp011118k

TEHRANI-BAGHA AR, MAHMOODI NM and MENGER FM (2010) Degradation of a persistent organic dye from colored textile wastewater by ozonation. Desalination 260 (1-3) 34-38. https://doi. org/10.1016/j.desal.2010.05.004

VESELY M, CEPPAN M and LAPCIK L (1991) Photocatalytic degradation of hydroxyethylcellulose in aqueous $\mathrm{Pt}-\mathrm{TiO}_{2}$ suspension. J. Photochem. Photobiol. A: Chem. 61 (3) 399-406. https://doi.org/10.1016/1010-6030(91)90023-M

WAN Y, SUN B, XU Z and CHAO W (2012) Effect of UV irradiation on wear protection of $\mathrm{TiO}_{2}$ and $\mathrm{Ni}$-doped $\mathrm{TiO}_{2}$ coatings. Appl. Surf. Sci. 258 (10) 4347-4350. https://doi.org/10.1016/j.apsusc.2011.12.111

WANG W, HUANG WJ, NI Y, LU CH, TAN LJ and XU ZZ (2013) Graphene supported $\beta \mathrm{NaYF} 4: \mathrm{Yb}^{3+}, \mathrm{Tm}^{3+}$ and $\mathrm{N}$ doped P25 nanocomposite as an advanced NIR and sunlight driven upconversion photocatalyst. Appl. Surf. Sci. 282 832-837. https:// doi.org/10.1016/j.apsusc.2013.06.066

WANG X, YAO Z, WANG J, GUO W and LI G (2008) Degradation of reactive brilliant red in aqueous solution by ultrasonic cavitation. Ultrason. Sonochem. 15 (1) 43-48. https://doi.org/10.1016/j. ultsonch.2007.01.008
WEBER EJ and ADAMS RL (1995) Chemical and sediment mediated reduction of the azo dye disperse blue 79. Environ. Sci. Technol. 29 (5) 1163-1170. https://doi.org/10.1021/es00005a005

WEI L, SHIFU C, WEI Z and SUJUAN Z (2009) Titanium dioxide mediated photocatalytic degradation of methamidophos in aqueous phase. J. Hazardous Mater. 164 (1) 154-160. https://doi.org/10.1016/j. jhazmat.2008.07.140

WENHUA L, HONG L, SUO'AN C, JIANQING Z and CHUNAN C (2000) Kinetics of photocatalytic degradation of aniline in water over TiO2 supported on porous nickel. J. Photochem. Photobiol. A: Chem. 131 (1-3) 125-132. https://doi.org/10.1016/S1010-6030(99)00232-4

XU GR, WANG JN and LI CJ (2013) Template directed preparation of $\mathrm{TiO}_{2}$ nanomaterials with tunable morphologies and their photocatalytic activity research. Appl. Surf. Sci. 279 103-108. https:// doi.org/10.1016/j.apsusc.2013.04.043

YANG MQ, ZHANG N and XU YJ (2013) Synthesis of fullerene-, carbon nanotube-, andgraphene- $\mathrm{TiO}_{2}$ nanocomposite photocatalysts for selective oxidation: a comparative study. ACS Appl. Mater. Interfaces 5 (3) 1156-1164. https://doi.org/10.1021/am3029798

ZHANG F, ZHAO J, SHEN T, HIDAKA H, PELIZZETTI E and SERPONE N (1998) TiO2-assisted photodegradation of dye pollutants II. Adsorption and degradation kinetics of eosin in $\mathrm{TiO} 2$ dispersions under visible light irradiation. Appl. Catal. B 15 (1-2) 147-156. https://doi.org/10.1016/S0926-3373(97)00043-X

ZHU G, QUE W and ZHANG J (2011) Synthesis and photocatalytic performance of $\mathrm{Ag}$-loaded $\beta-\mathrm{Bi}_{2} \mathrm{O}_{3}$ microspheres under visible light irradiation. J. Alloys Compd. 509 (39) 9479- 9486. https://doi. org/10.1016/j.jallcom.2011.07.046 